\title{
PENGARUH MOTIVASI KERJA DAN DISIPLIN KERJA TERHADAP KINERJA GURU MADRASAH
}

\author{
Ita Nurfadilah \\ IAIN Jember \\ itanurfadilah79@gmail.com \\ Umi Farihah \\ IAIN Jember \\ u_farihah@yahoo.com \\ DOI: 10.35719/jieman.v3i1.70
}

\begin{abstract}
Abstrak
Tujuan penelitian ini adalah untuk mengetahui pengaruh motivasi kerja dan disiplin kerja terhadap kinerja guru di Madrasah Tsanawiyah Negeri 2 Bondowoso. Penelitian ini dilatarbelakangi oleh adanya faktor yang mempengaruhi kinerja guru salah satunya motivasi kerja dan disipln kerja. Motivasi kerja merupakan salah satu faktor yang mempengaruhi terhadap kinerja. Motivasi kerja juga menjadi kebutuhan yang digunakan seseorang untuk melakukan suatu pekerjaan. Dalam meningkatkan kinerja guru tentunya tidak lepas dari dorongan diri sendiri ataupun dari luar, salah satunya yaitu kepala sekolah sebagai dorongan dari luar. Dan disiplin kerja merupakan salah satu faktor yang tidak kalah penting dari motivasi kerja. Sehingga disiplin sangat penting bagi pertumbuhan suatu lembaga dan organisasi untuk mendorong para anggotanya memenuhi tuntutan berbagai ketentuan yang telah ditetapkan. Penelitian ini menggunakan pendekatan kuantitatif dengan jenis penelitian asosiatif kausal serta metode penelitian survey yang dilakukan di Madrasah Tsanawiyah Negeri 2 Bondowoso. Simple random sampling digunakan sebagai teknik pengambilan sample dengan jumlah sampel sebanyak 30 guru. Teknik
\end{abstract}


pengumpulan data menggunakan angket dan dokumentasi. Analisis data menggunakan analisis regresi linier berganda dengan bantuan SPSS Version 22 for Windows. Hasil penelitian ini menunjukkan bahwa terdapat pengaruh motivasi kerja dan disiplin kerja terhadap kinerja guru di Madrasah Tsanawiyah Negeri 2 Bondowoso.

Kata Kunci: Motivasi kerja, Disiplin Kerja, Kinerja guru

\begin{abstract}
The purpose of this study was to determine the effect of work motivation and work discipline on teacher performance at Madrasah Tsanawiyah Negeri 2 Bondowoso. This research is motivated by the existence of factors that affect teacher performance, one of which is work motivation and work discipline. Work motivation is one of the factors that affect performance. Work motivation is also a need that someone uses to do a job. In improving teacher performance, of course, it cannot be separated from self or external encouragement, one of which is the principal as encouragement from outside. And work discipline is one factor that is no less important than work motivation. So that discipline is very important for the growth of an institution and organization to encourage its members to meet the demands of various provisions that have been set. This study uses a quantitative approach with causal associative research and survey research methods conducted at Islamic Junior Hight School two Bondowoso. Simple random sampling was used as a sampling technique with a sample size of 30 teachers. Data collection techniques using questionnaires and documen-tation. Data analysis used multiple linear regression analysis with the help of SPSS Version 22 for Windows. The results of this study indicate that there is an influence of work motivation and work discipline on teacher performance at Islamic Junior Hight School two Bondowoso.
\end{abstract}

Keywords: work motivation, work discipline, teacher performance

\title{
Pendahuluan
}

Bangsa Indonesia memiliki tantangan dalam meningkatkan mutu pendidikan sekaligus mutu sumber daya manusia sebagai salah satu penentu keberhasilan pendidikan. Suatu lembaga pendidikan dapat mencapai tujuannya jika didukung oleh sumber daya manusia 
yang berkualitas. Sumber daya manusia yang berkualitas dapat tercipta melalui pendidikan yang berkualitas. ${ }^{1}$

Penyelenggaran sistem pendidikan tidak akan berjalan dengan efektif dan efisien tanpa peran guru dan tenaga administrasi serta bendahara. Peran guru sangat penting karena merupakan penentu utama dalam keberhasilan proses pendidikan. ${ }^{2}$ Oleh karena itu guru perlu dibina dan dikembangkan secara terus menerus serta merencanakan program yang dapat meningkatkan kualitas kinerja guru dalam pelaksanaan pendidikan.

Dalam Undang-undang Nomor 14 Tahun 2005 tentang Guru dan Dosen Bab I pasal 1 ayat 1 yang berbunyi: "Guru adalah pendidik profesional dengan tugas utama mendidik, mengajar, membimbing, mengarahkan, melatih, menilai dan mengevaluasi peserta didik pada pendidikan anak usia dini jalur pendidikan formal, pendidikan dasar dan pendidikan menengah." 3

Salah satu keberhasilan sistem pendidikan nasional dapat dilihat dari kinerja gurunya. Kinerja adalah hasil kerja yang dicapai oleh seorang guru dalam menjalankan tugasnya sesuai dengan tanggung jawab yang diberikan kepadanya. Sedangkan kinerja guru merupakan hasil kerja yang dapat dicapai guru dalam suatu organisasi (sekolah), sesuai dengan wewenang dan tanggung jawab yang diberikan sekolah dalam upaya mencapai visi, misi, dan tujuan sekolah bersangkutan secara legal, tidak melanggar hukum dan sesuai dengan moral maupun etika. ${ }^{4}$ Salah satu faktor yang mempengaruh terhadap kinerja yaitu faktor kemampuan kerja dan faktor motivasi kerja. ${ }^{5}$

${ }^{1}$ Utari dan Rasto, "Pengaruh disiplin kerja terhadap kinerja guru". Jurnal pendidikan manajemen perkantoran 4, no. 2 (Juli 2019): 238.

${ }^{2}$ Siti Rodliyah, Manajemen Pendidikan sebuah Konsep dan Aplikasi (Jember: IAIN Jember Press, 2015), 45.

${ }^{3}$ Undang-Undang Nomor 14 tahun 2005 tentang Guru dan Dosen. 2016), 11.

4 Abdul Madjid, Pengembangan kinerja guru (Yogyakarta: Samudra Biru,

${ }^{5}$ Anwar Prabu Mangkunegara, Manajemen Sumberdaya Manusia Perusahaan (Bandung: PT Remaja Rosdakarya, 2014), 67. 
Motivasi kerja merupakan salah satu faktor yang memengaruhi terhadap kinerja. Menurut Husain Usmani, Motivasi kerja merupakan keinginan atau kebutuhan yang melatarbelakangi seseorang untuk bekerja. ${ }^{6}$ Dalam meningkatkan kinerja guru tentunya tidak lepas dari dorongan diri sendiri ataupun dari luar, salah satunya yaitu kepala sekolah atau pemimpin sebagai dorongan dari luar.

Perilaku yang timbul pada diri seseorang dalam menumbuhkan semangat kerja dapat mendorong tercapainya kebutuhan atau tujuan yang telah ditentukan. Disiplin kerja merupakan salah satu faktor yang tidak kalah penting dari motivasi kerja. Disiplin sangat penting bagi pertumbuhan organisasi baik secara per-orangan maupun kelompok. Menurut Siagian, disiplin merupakan tindakan manajemen untuk mendorong para anggota organisasi memenuhi tuntutan berbagai ketentuan yang telah ditetapkan. ${ }^{7}$

Madrasah Tsanawiyah Negeri 2 Bondowoso merupakan sebuah lembaga pendidikan berbasis Islam yang terletak di Jl. MT. Haryono No. 44 Badean Bondowoso. Berdasarkan observasi dan wawancara yang dilakukan di lapangan bahwa guru di Madrasah Tsanawiyah Negeri 2 Bondowoso sudah memiliki guru yang kompeten. Serta pembelajaran di Madrasah Tsanawiyah Negeri 2 Bondowoso sudah menerapkan pembelajaran online melalui website Madrasah Tsanawiyah Negeri 2 Bondowoso yang bisa diakses oleh peserta didik untuk melakukan pembelajaran. Dengan cara guru memberikan kode yang telah ditentukan oleh kepala bagian administrasi untuk masing-masing guru ataupun permata pelajaran. Akan tetapi, ada beberapa guru yang tidak disiplin dalam menjalankan tugas, tuntutan ataupun aturan yang ada dilembaga. Salah satunya guru yang tidak melakasanakan tugas pekerjaannya yaitu sering terlambat dalam mengajar di Elearning Madrasah Tsanawiyah Negeri 2 Bondowoso, maka peserta didikpun terlambat

${ }^{6}$ Husaini Usmani, Manajemen Teori, Praktik, dan Riset Pendidikan (Jakarta: PT Bumi Aksara, 2016), 276.

${ }^{7}$ Anis Syamsu Rizal, "Pengaruh Motivasi Kerja dan Disiplin Kerja terhadap Kinerja Guru SMP”. Jurnal Ulul Albab 23, No. 1 (2019), 17. 
akibat guru belum melaksanakan tugas yang seharusnya dilaksanakan. ${ }^{8}$ Akan tetapi, guru yang tidak melaksanakan tugasnya dapat diketahui oleh operator (TU). Serta data yang sudah ada di wabsite tersebut sudah masuk dan terbackup dalam web yang dipantau langsung oleh kepala TU dan operator dilembaga tersebut. Selain itu, kurang persaingan antar guru di Madrasah Tsanawiyah Negeri 2 Bondowoso membuat motivasi kerja dan disiplin kerja tidak maksimal serta mereka akan termotivasi jika material yang mereka dapatkan lebih dari kinerja mereka. ${ }^{9}$

Menurut Gibson kinerja guru dipengaruhi oleh Tiga faktor tersebut yaitu: (1) Faktor individu (kemampuan, keterampilan, latar belakang keluarga, pengalaman kerja, tingkat sosial dan demografi seseorang), (2) Faktor psikologis (persepsi, sikap, kepribadian, belajar dan motivasi). (3) Faktor organisasi (struktur organisasi, desain pekerjaan, kepemimpinan, sistem penghargaan atau reward system. ${ }^{1}$

Salah satu yang mempengaruhi kinerja guru dari faktor psikologi yaitu motivasi. Motivasi adalah suatu dorongan untuk memberikan stimulus kepada seseorang. Motivasi kerja guru adalah suatu proses menggerakan guru untuk berperilaku sesuai arahan pada upaya-upaya nyata dalam mencapai tujuan yang telah ditetapkan. ${ }^{1}$

Adapun macam-macam motivasi kerja yaitu intrinsik dan ekstrinsik. Motivasi Intrinsik adalah keinginan bertindak yang disebabkan oleh faktor pendorong dari dalam (internal) individu. Motivasi instrinsik dalam diri seorang guru misalnya, tanggung jawab guru dalam melaksanakan tugas, melaksanakan tugas dengan target yang jelas, memiliki tujuan yang jelas dan menantang,

${ }^{8}$ Ida Rohani, diwawancari oleh Peneliti, Bondowoso, 17 september 2020.

${ }^{9}$ Candra Ambar Basuki, diwawancari oleh Peneliti, Bondowoso, 31 Agustus 2020

1 Umi Farihah, "Analisis Pehgaruh Kebijakan Peningkatan Profesionalisme Guru terhadap Prestasi Kerja Guru," Jurnal Internasional Manajemen Pendidikan (2010):121.

1 Hamzah B. Uno, Teori Motivasi Kerja dan Pengukurannya (Jakarta: Bumi Aksara, 2010), 71-72. 
memiliki perasaan senang dalam bekerja, selalu berusaha untuk mengungguli orang lain serta mengutamakan prestasi dari apa yang dikerjakan guru. sedangkan motivasi ekstrinsik adalah motif-motif yang aktif dan berfungsi karena adanya perangsang dari luar atau faktor pendorong dari luar. Motivasi ekstrinsik seorang guru misalnya, selalu berusaha memenuhi kebutuhan hidup dan kerjanya, senang memperoleh pujian dari apa yang dia kerjakan, bekerja dengan harapan ingin memperoleh reward, serta bekerja dengan harapan ingin memperoleh perhatian. ${ }^{1}$

Menurut Mc. Celland motivasi meliputi : (a) Kebutuhan akan prestasi (Need for achievement), merupakan gaya pergerakan yang memotivasi semangat bekerja seseorang. Dimana seseorang akan mengambil tugas yang dapat dipertanggungjawabkan secara pribadi atas perbuatan-perbuatannya. (b) Kebutuhan akan afiliasi, kebutuhan akan perasaan yang diterima oleh orang lain dilingkungan tempat tinggal dan bekerja. Adanya keinginan seseorang untuk bekerjasama, senang bergaul, berusaha mendapatkan persetujuan orang lain, melaksanakan tugas-tugasnya secara efektif jika bekerja dengan orang lain. (c) Kebutuhan akan kekuasaan, merangsang dan memotivasi gairah kerja seseorang serta mengarahkan semua kemampuannya demi mencapai kekuasaan atau kedudukan yang terbaik. (d) Menyatakan ada tiga type dasar kebutuhan motivasi yaitu kebutuhan akan prestasi, afiliasi, dan kekuasaan. Dalam hal ini seorang pemimpin memotivasi bawahannya dengan menye-diakan peralatan, membuat suasana yang kondusif, kesempatan promosi bagi bawahan agar bersemangat dalam mencapai tujuan. (e) Merupakan pengembangan teori hierarki kebutuhan Maslow yang menjadi dua teori yaitu interinsik dan ekstrinsik. ${ }^{1}$

Selain motivasi kerja, adapula yang mempengaruhi kinerja dari faktor psikolog yaitu disiplin kerja. Disiplin kerja menurut Robbins yang dikutip oleh Desy Arisandy disiplin kerja dapat diartikan sebagai suatu sikap dan perilaku yang dilakukan secara

1 Uno, Teori Motivasi, 75.

1 Sofyan Tsauri, Mananjemen 3 Sumber Daya Manusia (Jember: STAIN Jember Press, 2013), 182. 
sukarela dengan penuh kesadaran dan kesediaan mengikuti peraturan-peraturan yang telah ditetapkan oleh perusahaan atau atasan, baik tertulis maupun tidak tertulis. ${ }^{1}$

Adapun faktor yang mempengaruhi disiplin kerja yaitu (a) Frekuensi kehadiran merupakan salah satu tolak ukur untuk menentukan tingkat kedisiplinan guru. Semakin tinggi frekuensi kehadiran atau rendah tingkat absensi maka semakin tinggi disiplin guru. (b) Tingkat kewaspadaan dalam pekerjaannya selalu penuh perhitungan dan ketelitian. Memiliki tingkat kewaspadaan yang tinggi baik terhadap dirinya maupun terhadap pekerjaannya. (c) Mematuhi standart kerja, seorang pekerja harus mematuhi semua standar kerja yang telah ditetapkan sesuai dengan aturan dan pedoman kerja untuk menghindari kecelakaan kerja atau minimalisasi. (d) Tujuan mematuhi peraturan kerja adalah membuat pekerja nyaman dan lancar dalam bekerja. (e) Setiap pekerja membutuhkan etika profesi untuk menciptakan suasana yang harmonis, saling menghormatin antar sesama. ${ }^{1}$

Disiplin kerja memberikan suatu manfaat yang besar bagi lembaga pendidikan maupun tenaga pendidikan. Adanya disiplin kerja ini akan menjamin ketertiban dan kestabilan dalam melaksanakan tugas sehingga memperoleh hasil yang optimal. Contoh kecil dalam disiplin kerja yaitu datang tepat waktu, tertib, dan teratur. Tiga hal tersebut harus dimiliki oleh setiap tenaga pendidikan karena mereka akan menjadi contoh atau panutan bagi peserta didik. Selain itu berpakaian dengan rapi juga menjadi salah satu dari implementasi disiplin kerja dalam menaati peraturan. ${ }^{1}$

Hal ini sejalan dengan penelitian sebelumnya yang dilakukan oleh Lilik Sundari Tahun 2020. Hasil penelitiannya menunjukkan

1 Desy Arisandy, "Hubungañ antara Persepsi Karyawan terhadap Disiplin Karyawan Bagian Produksi Kramik "Ken Lila Production," Jurnal Psyche 1, no. 2, (Desember 2004): 6.

1 Lijat Poltak Sinambela, Manájemen Sumber Daya Manusia (Jakarta: PT Bumi Aksara. 2017), 333.

1 Indriani \& Sutanto, "Hubungân Lingkungan Kerja, Disiplin Kerja, dan Kinerja Karyawan," Jurnal Manajemen dan Kewirausahaan 17, no. 2, (2015): 137. 
bahwa terdapat pengaruh yang signifikan variabel motivasi kerja terhadap kinerja guru di Madrasah Aliyah Negeri Bondowoso. Selain itu, penelitian sebelumnya dilakukan oleh Kaliri tahun 2008 dengan hasil penelitiannya menyatakan bahwa motivasi kerja dan disiplin kerja sama-sama berpengaruh secara signifikan terhadap kinerja guru di SMA Negeri kabupaten pemalang. Jadi apabila motivasi dan disiplin semakin tinggi maka kinerja guru akan semakin baik.

\section{Pembahasan}

\section{Motivasi Kerja Guru di Madrasah Tsanawiyah Negeri 2 Bondowoso}

Angket motivasi kerja guru diberikan untuk mengetahui motivasi kerja guru di Madrasah Tsanawiyah Negeri 2 Bondowoso. Berdasarkan hasil penelitan diperoleh motivasi kerja guru dengan kategori sangat tinggi sebanyak 9 guru dengan presentase 30\%, motivasi kerja dengan kategori tinggi sebanyak 20 guru dengan presentase $67 \%$, motivasi kerja dengan kategori sedang sebanyak 1 guru dengan presentase 3\%, motivasi kerja dengan kategori rendah sebanyak o guru dengan presentase o\%, dan motivasi kerja dengan kategori sangat rendah sebanyak o guru dengan presentase $\mathrm{o} \%$ seperti pada tabel di bawah ini:

Tabel 1. Hasil Motivasi Kerja Guru

\begin{tabular}{cccc}
\hline Nilai & Frekuensi & Presentase & Kategori \\
\hline $123-145$ & 9 & $30 \%$ & Sangat Tinggi \\
$100-122$ & 20 & $67 \%$ & Tinggi \\
$77-99$ & 1 & $3 \%$ & Sedang \\
$54-76$ & 0 & $0 \%$ & Rendah \\
$30-53$ & 0 & $0 \%$ & Sangat Rendah \\
\hline
\end{tabular}

berdasarkan data hasil angket motivasi kerja di atas yang diberikan dengan 29 item pernyataan. Diperoleh data hasil angket motivasi kerja seperti pada gambar di bawah ini: 


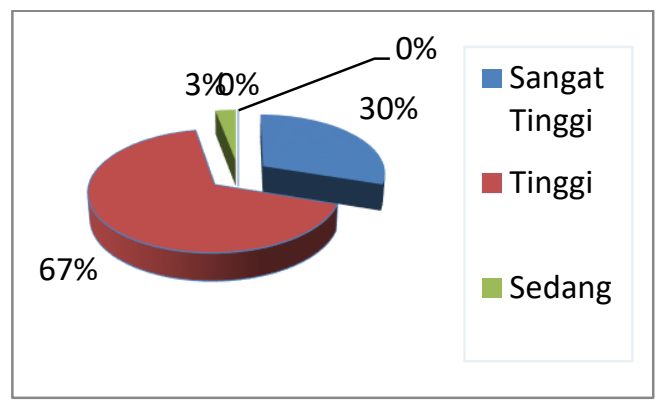

Gambar 2. Motivasi Kerja Guru di Madrasah Tsanawiyah Negeri 2 Bondowoso

Berdasarkan diagram di atas, dapat disimpulkan bahwa motivasi kerja guru dengan kategori sangat tinggi sebesar 30\%, motivasi kerja guru dengan kategori tinggi sebesar $67 \%$, dan motivasi kerja guru dengan kategori sedang sebesar 3\%. Maka dapat disimpulkan bahwa motivasi kerja guru di Madrasah Tsanawiyah Negeri 2 Bondowoso rata-rata berkategori tinggi sebesar $67 \%$.

Salah satu penyebab motivasi kerja guru di Madrasah Tsanawiyah Negeri 2 Bondowoso tergolong tinggi dapat dilihat dari rata-rata umur responden. Dimana kebanyakan responden dalam penelitian ini berusia 35 tahun - 45 tahun sebesar $47 \%$. Umur dapat mempengaruhi seseorang dalam bekerja. Jika usianya sudah lanjut usia maka seseorang akan mengalami penurunan semangat atau kurangnya motivasi. Sebaliknya, usia muda cenderung lebih semangat atau motivasi kerjanya tinggi dalam bekerja. Guru yang menjadi responden dalam penelitian ini tergolong sudah lanjut usia. Meskipun, usia guru di Madrasah Tsanawiyah Negeri 2 Bondowoso tergolong usia lanjut, akan tetapi guru-guru tersebut tetap produktif dalam bekerja sehingga hal tersebut membuat guru bersemangat dalam bekerja dan motivasi yang dimiliki guru tergolong tinggi.

\section{Disiplin Kerja Guru di Madrasah Tsanawiyah Negeri 2 Bondowoso.}

Angket disiplin kerja guru diberikan untuk mengetahui disiplin kerja guru di Madrasah Tsanawiyah Negeri 2 Bondowoso. 
Berdasarkan hasil penelitan diperoleh disiplin kerja dengan kategori sangat tinggi sebanyak 24 guru dengan presentase $80 \%$, disiplin kerja dengan kategori tinggi sebanyak 6 guru dengan presentase $20 \%$, sementara disiplin kerja dengan kategori sedang, rendah dan sangan rendah sebanyak o guru dengan presentase o\% seperti pada tabel di bawah ini:

Tabel 2. Hasil Disiplin Kerja

\begin{tabular}{cccc}
\hline Nilai & Frekuensi & Presentase & Kategori \\
\hline $72-85$ & 24 & $80 \%$ & Sangat Tinggi \\
$58-71$ & 6 & $20 \%$ & Tinggi \\
$44-57$ & 0 & $0 \%$ & Sedang \\
$30-43$ & 0 & $0 \%$ & Rendah \\
$15-29$ & 0 & $0 \%$ & Sangat Rendah \\
\hline
\end{tabular}

Berdasarkan data hasil angket disiplin kerja di atas yang diberikan dengan 17 item pernyataan. Diperoleh data hasil angket disiplin kerja guru seperti pada gambar di bawah ini:

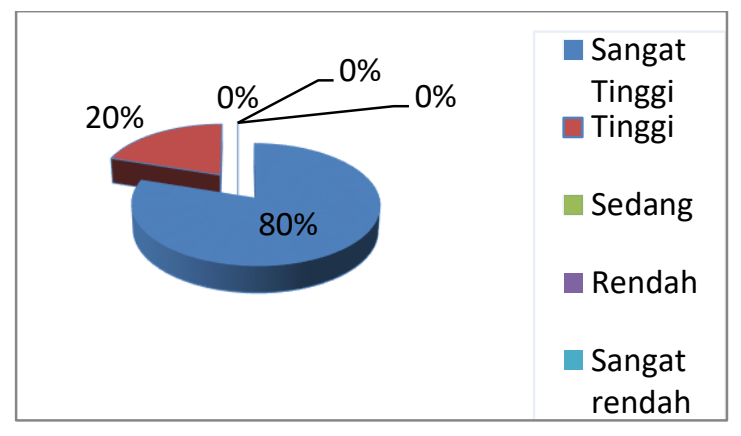

Gambar 3. Disiplin Kerja Guru di Madrasah Tsanawiyah Negeri 2 Bondowoso

Berdasarkan gambar di atas, dapat disimpulkan bahwa disiplin kerja guru dengan kategori sangat tinggi sebesar 8o\% dan disiplin kerja guru dengan kategori tinggi sebesar 20\%. Maka dapat 
disimpulkan bahwa disiplin kerja guru di Madrasah Tsanawiyah Negeri 2 Bondowoso rata-rata berkategori sangat tinggi sebesar 8o\%.

Disiplin kerja di Madrasah Tsanawiyah Negeri 2 Bondowoso dapat dikatakan memiliki rata-rata sangat tinggi. Hal tersebut disebabkan oleh tuntutan peraturan lembaga sekolah. Jika setiap responden patuh terhadap peraturan lembaga sekolah, maka disiplin kerja guru dapat dikatakan tinggi begitu pula sebaliknya. Sehingga disiplin kerja guru itu tidak terpengaruh oleh masa kerja pada setiap responden.

\section{Kinerja guru di Madrasah Tsanawiyah Negeri 2 Bondowoso.}

Angket kinerja guru diberikan untuk mengetahui kinerja guru di Madrasah Tsanawiyah Negeri 2 Bondowoso. Berdasarkan hasil penelitan diperoleh kinerja dengan kategori sangat tinggi sebanyak 9 guru dengan presentase 30\%, kinerja dengan kategori tinggi sebanyak 20 guru dengan presentase $67 \%$, kinerja dengan kategori sedang sebanyak 1 guru dengan presentase 3\%, kinerja dengan kategori rendah dan sangat rendah sebanyak o guru dengan presentase $0 \%$ seperti pada tabel di bawah ini:

Tabel 3. Kinerja Guru

\begin{tabular}{cccc}
\hline Nilai & Frekuensi & Presentase & Kategori \\
\hline $190-225$ & 9 & $30 \%$ & Sangat Tinggi \\
$154-189$ & 20 & $67 \%$ & Tinggi \\
$118-153$ & 1 & $3 \%$ & Sedang \\
$82-117$ & 0 & $0 \%$ & Rendah \\
$45-81$ & 0 & $0 \%$ & Sangat Rendah \\
\hline
\end{tabular}

Berdasarkan data hasil angket kinera guru pada tabel 3 yang diberikan dengan 45 item pernyataan. Diperoleh data hasil angket kinerja guru seperti pada gambar di bawah ini: 


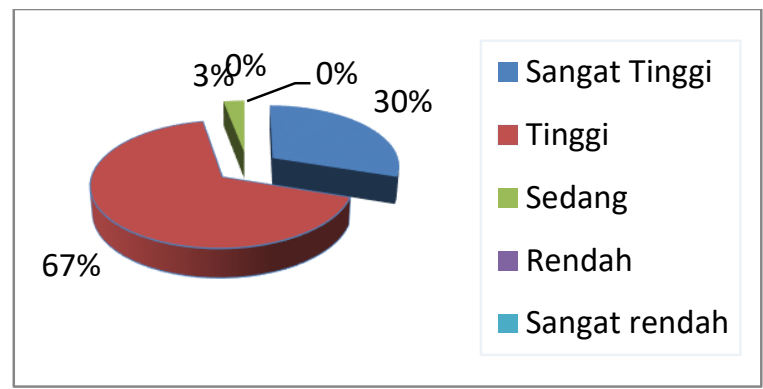

Gambar 3. Kinerja Guru di Madrasah Tsanawiyah Negeri 2 Bondowoso

Berdasarkan diagram di atas, dapat disimpulkan bahwa kinerja guru dengan kategori sangat tinggi sebesar 30\%, kinerja guru dengan kategori tinggi sebesar $67 \%$, dan kinerja guru dengan kategori sedang sebesar 3\%. Maka dapat disimpulkan bahwa kinerja guru di Madrasah Tsanawiyah Negeri 2 Bondowoso rata-rata berkategori tinggi sebesar $67 \%$.

Kinerja guru di Madrasah Tsanawiyah Negeri 2 Bondowoso dapat dikatakan memiliki rata-rata yang tinggi. Hal tersebut disebabkan oleh umur setiap responden. Selain itu, umur setiap responden dalam penelitian ini sebesar $47 \%$ dengan rata-rata setiap responden berusia 35-45 tahun. Sehingga produktivitas dalam kinerja guru itu dipengaruhi oleh umur. Meskipun umur dari setiap responden tersebut tergolong kurang produktif akan tetapi dengan adanya dukungan dan tuntutan dari sekolah maka kinerja guru semakin tinggi atau baik.

\section{Uji Prasyarat}

Sebelum melakukan uji regresi linier berganda terlebih dahulu dilakukan uji prasyarat yaitu uji normalitas, kolinierutas, heterokedastisitas, dan autokorelasi.

a. Uji Normalitas

Hasil perhitungan dengan bantuan SPSS for windows version 22 terkait data motivasi kerja dan disiplin kerja terhadap kinerja guru, dapat lihat pada gambar di bawah ini: 


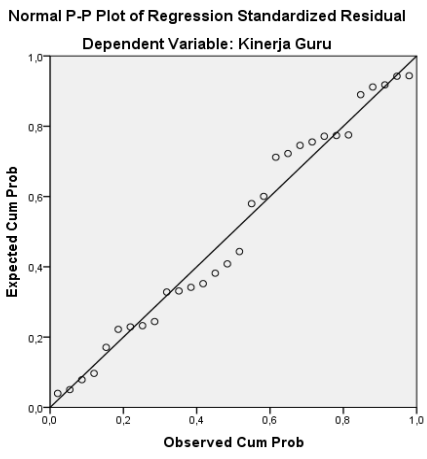

Gambar 4. Uji Normalitas Motivasi Kerja dan Disiplin Kerja Terhadap Kinerja guru

Berdasarkan gambar 4, dapat dilihat normal P-P plot of regression standardized residual menunjukkan bahwa data menyebar pada sekitar garis diagonal atau mengikuti garis diagonal, maka dapat disimpulkan bahwa data tersebut berdistribusi normal. Sehingga asumsi pernyataan normalitas pada regresi ini sudah terpenuhi.

b. Uji Kolinieritas

Berdasarkan hasil perhitungan dengan bantuan SPSS for windows version 22 terkait data motivasi kerja dan disiplin kerja terhadap kinerja guru, dapat lihat pada tabel di bawah ini:

Tabel 4. Uji Kolinieritas

\begin{tabular}{|c|c|c|}
\hline \multirow{2}{*}{ Model } & \multicolumn{2}{|c|}{ Collinearity Statistics } \\
\cline { 2 - 3 } & Tolerance & VIF \\
\hline Motivasi Kerja (X1) &, 869 & 1,151 \\
\hline Disiplin Kerja (X2) &, 869 & 1,151 \\
\hline
\end{tabular}

Berdasarkan tabel 4, menunjukkan bahwa nilai VIF pada semua variabel $<2$, maka tidak terjadi kolenieritas pada 
regresi ini atau tidak ada gangguan kolinieritas pada penelitian ini.

c. Uji Heteroskedastisitas

Berdasarkan hasil perhitungan dengan bantuan SPSS for windows version 22 diperoleh scatterplot variabel independen terhadap kinerja guru yang dapat lihat pada gambar di bawah ini:

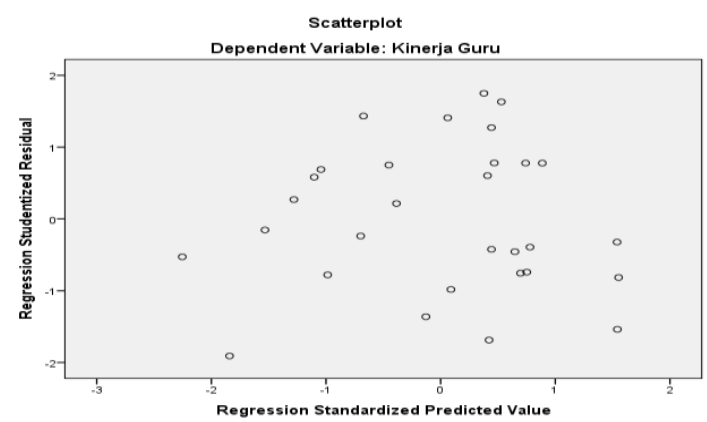

Gambar 5. Uji Heterokedastisitas

Berdasarkan gambar di atas, dapat dilihat scatterplot menunjukkan bahwa tidak terdapat pola yang jelas, serta titik-titik menyebar di atas dan di bawah angka o pada sumbu Y, maka dapat disimpulkan bahwa tidak terjadi heterokedastisitas pada penelitian ini.

d. Uji autokorelasi

Berdasarkan hasil perhitungan dengan bantuan SPSS for windows version 22 diperoleh angka $\mathrm{D}-\mathrm{W}=1,750$, yang dapat lihat pada tabel di bawah ini:

Tabel 5. Uji Autokorelasi

Model Summary

\begin{tabular}{|c|r|r|r|r|r|}
\hline Model & $\mathrm{R}$ & $\begin{array}{r}\mathrm{R} \\
\text { Square }\end{array}$ & $\begin{array}{c}\text { Adjusted R } \\
\text { Square }\end{array}$ & $\begin{array}{r}\text { Std. Error } \\
\text { of the Estimate }\end{array}$ & $\begin{array}{c}\text { Durbin- } \\
\text { Watson }\end{array}$ \\
\hline 1 &, 4 &, 211 &, 152 & 15,295 & 1,750 \\
\hline
\end{tabular}

a. Predictors: (Constant), Disiplin Kerja, Motivasi Kerja 
b. Dependent Variable: Kinerja Guru

Dari tabel 5, menunjukkan bahwa angka D-W = 1,750, maka angka tersebut terletak diantara 1,65 sampai 2,35. Dapat disimpulkan bahwa tidak terjadi autokorelasi atau masalah dalam penelitian ini. Sehingga analisis regresi linier berganda untuk uji hipotesis penelitian ini dapat dilakukan.

\section{Pengaruh Motivasi Kerja dan Disiplin Kerja Berpengaruh Secara Bersama-Sama terhadap Kinerja Guru di Madrasah Tsanawiyah Negeri 2 Bondowoso}

Analisis regresi linier berganda digunakan untuk mengetahui pengaruh motivasi kerja dan disiplin kerja secara bersama-sama terhadap kinerja guru. Sebelum dilakukan analisis regresi linier berganda peneliti terlebih dahulu melakukan uji prasyarat yaitu uji normalitas, kolinieritas, heterokedastisitas, dan autokorelasi. Hasil semua uji prasyarat terpenuhi. Selanjutnya, dilakukan uji hipotesis, kesimpulan penelitian dinyatakan signifikan apabila $F_{\text {hitung }}>F_{\text {tabel }}$ maka $\mathrm{H}_{\mathrm{a}} \mathbf{1}$ diterima dan $\mathrm{H}_{\mathrm{o}} \mathbf{1}$ ditolak begitu pula sebaliknya jika $\mathrm{F}_{\text {hitung }}$ $<\mathrm{F}_{\text {tabel }}$ maka $\mathrm{H}_{\mathrm{a}} \mathrm{l}$ ditolak dan $\mathrm{H}_{\mathrm{o}}$ diterima. Adapun rekapitulasi hasil regresi linier berganda motivasi kerja dan disiplin kerja terhadap kinerja guru dapat dilihat pada tabel di bawah ini:

Tabel 6. Rekapitulasi Hasil Regresi Linier Berganda Motivasi Kerja dan Disiplin Kerja terhadap Kinerja Guru

\begin{tabular}{llllll}
\hline $\mathbf{F}_{\text {hitung }}$ & $\mathbf{F}_{\text {tabel }}$ & Konstanta & R square & $\boldsymbol{a}$ & Keputusan $\left(\mathbf{H}_{\mathbf{a}} \mathbf{1}\right)$ \\
\hline 3,606 & 3,340 & 4,318 & 0,221 & 0,05 & Diterima \\
\hline
\end{tabular}

Dengan hasil perhitungan SPSS for windows version 22 pada tabel 6, diperoleh nilai $F_{\text {hitung }}$ sebesar = 3,606 lebih besar dari $F_{\text {tabel }}=$ 3,340 dengan taraf kepercayaan o,05. Maka $\mathrm{H}_{\mathrm{a}} 1$ diterima dan $\mathrm{H}_{\mathrm{o}} 1$ ditolak. Sehingga dapat disimpulkan bahwa terdapat pengaruh signifikan motivasi kerja dan disiplin kerja secara bersama-sama terhadap kinerja guru di Madrasah Tsanawiyah Negeri 2 Bondowoso. Artinya semakin tinggi motivasi dan disiplin kerja maka akan 
semakin tinggi kinerja guru sebesar 22,1\%. Sedangkan sisanya sebesar $77,9 \%$ dipengaruhi oleh dimensi lain diluar penelitian ini.

Hasil di atas menunjukkan bahwa motivasi kerja dan disiplin kerja secara bersama-sama berpengaruh terhadap kinerja guru. Jika motivasi kerja dan disiplin kerja guru tinggi maka kinerja guru akan semakin baik, begitu pula sebaliknya.

Hal ini sejalan dengan penelitian Kaliri disebuah lembaga pendidikan dikabupaten pemalang. Dalam penelitiannya dia menemukan bahwa terdapat pengaruh secara simultan disiplin kerja dan motivasi kerja secara bersama-sama terhadap kinerja guru dengan perbandingan $F_{\text {hitung sebesar } 12,756}$ dan $F_{\text {tabel }} 3,44 .{ }^{1}$ Begitu pula hasil penelitian dari Anis Syamsu Rizal disebuah lembaga pendidikan sekolah menengah pertama. Dimana penelitian tersebut menemukan bahwa terdapat pengaruh motivasi kerja dan disiplin kerja secara bersama-sama terhadap kinerja guru dengan perbandingan $\mathrm{F}_{\text {hitung }}$ 114,957 dengan $\mathrm{F}_{\text {tabel 3,06. }}{ }^{1}$

Hal ini dapat dijadikan rujukan bagi seorang pemimpin untuk selalu memberi motivasi kerja dan tegas terhadap disiplin kerja guru, karena motivasi kerja dan disiplin kerja guru dapat mempengaruhi terhadap kinerja guru. Hal ini sesuai dengan teori Gibson yang menyatakan bahwa faktor kinerja guru dipengaruhi oleh tiga faktor salah satunya dari faktor psikologi yang terdiri dari persepsi, sikap, kepribadian, belajar dan motivasi. ${ }^{1}$ Faktor psikologi ${ }^{9}$ yang ditekankan dalam penelitian ini dari faktor motivasi dan disiplin atau sikap.

Selain itu dalam meningkatkan kinerja guru seorang pemimpin harus memperhatikan motivasi kerja dan disiplin kerja. Hal ini, sesuai dengan teori yang dikemukankan oleh Schunk,

1 Kaliri, "Pengaruh Disiplin dan Motivasi Kerja terhadap Kinerja Guru pada SMA Negeri di Kabupaten Pemalang.” Tesis. Universitas Negeri Semarang (2008), 125.

1 Mustika Sulistio Ningsih, "Pêngaruh Motivasi Kerja terhadap Kinerja Guru di MA Al-Hikmah Wayhalim Kedaton Bandar Lampung." Skripsi, UIN Raden Intan Lampung (2017), 61.

1 Umi Farihah, "Analisis Penggaruh Kebijakan Peningkatan Profesionalisme Guru terhadap Prestasi Kerja Guru.” Jurnal Internasional Manajemen Pendidikan (2010): 121. 
Pintrich, dan Meece yang menyatakan bahwa motivasi kerja berpengaruh terhadap kinerja seseorang. ${ }^{2}$ Dan hal ini juga didukung oleh pendapat Hamzah B Uno bahwa motivasi dipengaruh oleh faktor yang mendorong seseorang untuk mencapai tujuannya. Faktor tersebut yaitu faktor internal dan eksternal. Selain itu, motivasi setiap guru berbeda dengan motivasi guru lainnya, perbedaan tersebut menimbulkan hasil kinerja yang berbeda pula. ${ }^{2}$

Kedisiplinan juga menentuan kinerja guru. Menurut Robbins yang dikutip oleh Desy Arisandy disiplin kerja dapat diartikan sebagai suatu sikap dan perilaku yang dilakukan secara sukarela dengan penuh kesadaran dan kesediaan mengikuti peraturanperaturan yang telah ditetapkan oleh perusahaan atau atasan, baik tertulis maupun tidak tertulis. ${ }^{2}$ Seorang guru yang memiliki kedisiplinan yang tinggi maka menghasilkan kinerja yang baik dan tepat waktu dalam menyelesaikan suau tugas. Hal ini, sejalan dengan teori Robbins bahwa setiap responden yang patuh dan taat terhadap peraturan maka akan berpengaruh terhadap kinerja guru itu sendiri. Serta kedisiplinan itu harus dimiliki oleh setiap pekerja, khususnya didunia lembaga pendidikan agar bisa menjadi pekerja yang profesional. Semakin baik kedisiplinan seorang pekerja maka akan semakin tinggi pula kinerja yang dapat dicapai.

\section{Pengaruh motivasi kerja dan disiplin kerja berpengaruh secara individu terhadap kinerja guru di Madrasah Tsanawiyah Negeri 2 Bondowoso.}

Analisis regresi linier berganda digunakan untuk mengetahui pengaruh motivasi kerja dan disiplin kerja secara individu terhadap kinerja guru. Sebelum dilakukan analisis regresi linier berganda

2 Eliyanto, "Pengaruh Motiva\$i Kerja dan Lingkungan Kerja terhadap Kinerja Guru SMA Muhammadiyah di Kabupaten Kebumen.” Jurnal Pendidikan Madrasah 3, no.1. (2018): 178.

2 Hamzah B Uno, Teori Motivasi Kerja dan Pengukurannya (Jakarta: Bumi Aksara, 2019), 65.

2 Desy Arisandy, Hubungan² antara Persepsi Karyawan terhadap Disiplin Karyawan Bagian Produksi Kramik “Ken Lila Production”. Jurnal Psyche 1 No 2. (2004): 6. 
peneliti terlebih dahulu melakukan uji prasyarat yaitu uji normalitas, kolinieritas, heterokedastisitas, dan autokorelasi. Hasil semua uji prasyarat terpenuhi. Selanjutnya, dilakukan uji hipotesis. Kesimpulan penelitian dinyatakan signifikan apabila $t_{\text {hitung }}>\mathrm{t}_{\text {tabel }}$ maka $\mathrm{H}_{\mathrm{a}} 1$ diterima dan $\mathrm{H}_{\mathrm{o}}$ ditolak begitu pula sebaliknya jika $\mathrm{t}_{h i t u n g}$ $<\mathrm{t}_{\text {tabel }}$ maka $\mathrm{H}_{\mathrm{a}} \mathbf{l}$ ditolak dan $\mathrm{H}_{\mathrm{o}}$ diterima. Adapun rekapitulasi hasil regresi linier berganda motivasi kerja dan disiplin kerja terhadap kinerja guru dapat dilihat pada tabel di bawah ini:

Tabel 7. Rekapitulasi Hasil Regresi Linier Berganda Motivasi Kerja dan Disiplin Kerja terhadap Kinerja Guru

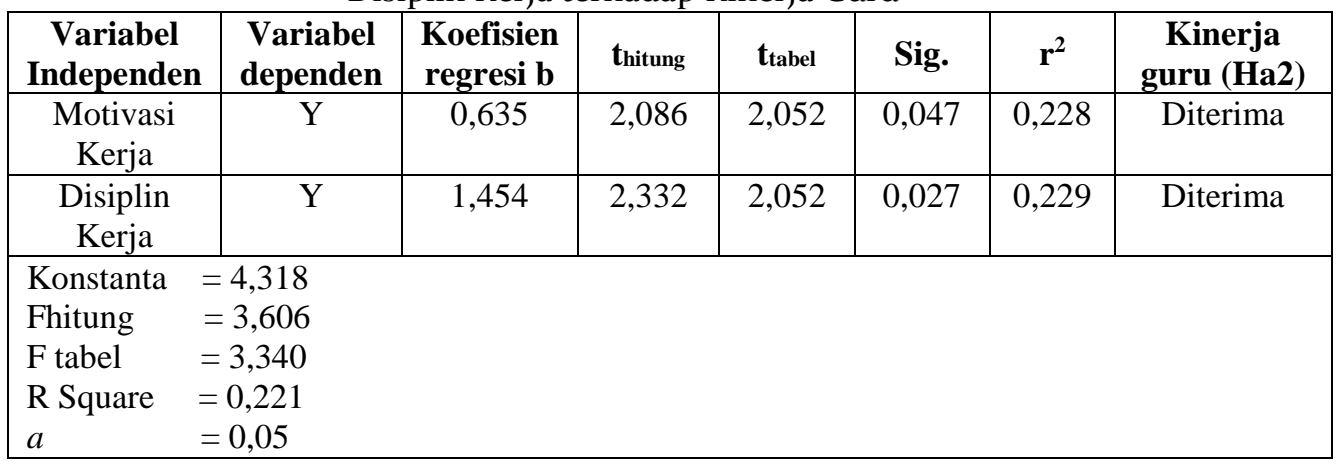

Berdasarkan tabel di atas, hasil estimasi dari pengaruh motivasi kerja dan disiplin kerja dapat dinyatakan sebagai berikut:

$$
\begin{aligned}
& Y=a+b_{1} X_{1}+b_{2} X_{2} \\
& Y=4,318+0,635 X_{1}+1,454 X_{2}
\end{aligned}
$$

Pada analisis regresi linier berganda diperoleh konstanta sebesar 4,318. variabel motivasi kerja $\left(\mathrm{X}_{1}\right)$ memiliki koefisien regresi sebesar 0,635. Artinya jika variabel bebas $\mathrm{X}_{1}$ berubah menjadi satu satuan maka variabel Y akan berubah sebesar o,635 dengan asumsi bebas lainnya. Dengan menambah satu nilai motivasi kerja maka kinerja guru akan meningkat sebesar 63,5\%. Sedangkan pada koefisien determinan parsial $\left(\mathrm{r}^{2}\right)$ variabel motivasi kerja sebesar 0,228 atau 2,28\% dapat diartikan bahwa sumbangan variabel motivasi kerja 
$\left(\mathrm{X}_{1}\right)$ terhadap kinerja guru $(\mathrm{Y})$ sebesar 2,28\%. Sedangkan 97,72\% dipengaruhi oleh faktor lain yang tidak dibahas dalam penelitian.

Koefisien regresi pada variabel disiplin kerja $\left(\mathrm{X}_{2}\right)$ sebesar 1,454. Artinya jika variabel bebas $X_{2}$ berubah menjadi satu satuan maka variabel $\mathrm{Y}$ akan berubah sebesar 1,454 dengan asumsi bebas lainnya. Dengan menambah satu nilai disiplin kerja maka kinerja guru akan meningkat sebesar $145,4 \%$. Sedangkan pada koefisien determinan parsial $\left(\mathrm{r}^{2}\right)$ variabel motivasi kerja sebesar 0,229 atau 2,29\% dapat diartikan bahwa sumbangan variabel disiplin kerja $\left(\mathrm{X}_{1}\right)$ terhadap kinerja guru (Y) sebesar 2,29\%. Sedangkan 97,71\% dipengaruhi oleh faktor lain yang tidak dibahas dalam penelitian.

Setelah dilaksankan analisis regresi linier bergandan dengan menggunakan uji statistik $\mathrm{t}$ terbukti bahwa hipotetsis alternatif 2 (Haz) diterima, sehingga dapat disimpulkan bahwa secara individu motivasi kerja dan disiplin kerja berpengaruh signifikan terhadap kinerja guru di Madrasah Tsanawiyah Negeri 2 Bondowoso. Dari hasil uji t hitung dari masing-masing variabel dapat dilihat sebagai berikut:

a. Pengaruh motivasi kerja terhadap kinerja guru di Madrasah Tsanawiyah Negeri 2 Bondowoso.

Motivasi kerja $\left(\mathrm{X}_{1}\right)$, diketahui nilai $\mathrm{t}_{\text {hitung }}=2,086$ lebih besar dari $t_{\text {tabel }}=2,052$ dengan taraf signifikan $5 \%$. Dapat disimpulkan bahwa variabel motivasi kerja secara individu berpengaruh terhadap kinerja guru di Madrasah Tsanawiyah Negeri 2 Bondowoso. Hal ini menunjukkan bahwa semakin tinggi motivasi kerja maka akan semakin tinggi pula kinerja guru, begitupun sebaliknya.

Variabel motivasi kerja guru terdiri dari dua sub variabel yaitu interinsik dan ekstrinsik dengan 29 item pernyataan dan 10 indikator. Pada setiap sub variabel diperoleh nilai tertinggi pada motivasi interinsik dengan indikator tanggung jawab guru dalam melaksanakan tugas, dengan item pernyataan pada nomor 2 yaitu "tugas merupakan tanggung jawab saya". Dalam hal ini dapat diketahui bahwa guru Madrasah Tsanawayih Negeri 2 
Bondowoso banyak yang memiliki tanggung jawab yang besar terhadap tugas yang diberikan. Dengan tanggung jawab tersebut menjadikan motivasi intrinsik sebagai motivasi tertinggi dalam meningkatkan kinerja guru di Madrasah Tsanawayih Negeri 2 Bondowoso.

Sedangkan untuk nilai terendah pada dua dimensi ini terletak pada motivasi eksterinsik dengan indikator senang memperoleh pujian dari apa yang dikerjakan, dengan item peryataan pada nomor 22 yaitu "Ketika saya mendapat pujian, hal tersebut mendorong saya untuk bekerja lebih baik lagi”. Dalam hal ini diketahui bahwa guru di Madrasah Tsanawayih Negeri 2 Bondowoso

b. Pengaruh disiplin kerja terhadap kinerja guru di Madrasah Tsanawiyah Negeri 2 Bondowoso

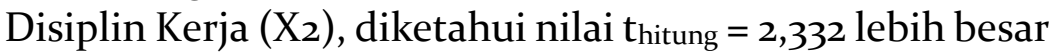
dari $t_{\text {tabel }}=2,052$ dengan taraf signifikan 5\%. Dapat disimpulkan bahwa variabel disiplin kerja secara individu berpengaruh terhadap kinerja guru di Madrasah Tsanawiyah Negeri 2 Bondowoso. Hal ini menunjukkan bahwa semakin tinggi disiplin kerja guru maka semakin tinggi pula kinerja guru, begitupun sebaliknya.

Pada variabel disiplin kerja terdiri dari empat sub variabel yaitu disiplin waktu, menengakan aturan, sikap dan disiplin dalam mengajar dengan 17 item peryataan. Pada setiap sub variabel diperoleh nilai tertinggi pada disiplin menegakkan aturan dengan indikator daftar hadir, dengan item peryataan pada nomor 7 yaitu "jika ingin meninggalkan sekolah, guru mengonfirmasikan kepada sekolah" diketahui bahwa guru di Madrasah Tsanawayih Negeri 2 Bondowoso sangat mematuhi terhadap peraturan yang telah ditetapkan dilembaga tersebut. Dengan demikian guru sangat menjunjung tinggi kedisiplinan sehingga dapat meningatkan kinerja guru di Madrasah Tsanawayih Negeri 2 Bondowoso. 
Sedangkan untuk nilai terendah pada empat sub variabel ini terletak pada disiplin waktu dengan indikator datang tepat waktu, dengan item peryataan pada nomor 1 yaitu "datang kesekolah sebelum jam pelajaran". Dalam hal ini diketahui bahwa guru Madrasah Tsanawayih Negeri 2 Bondowoso kurang menghargai waktu dan tidak patuh terhadap aturan atau disiplin. Dengan demikin guru perlu dteguran agar guru dapat disiplin.

Hasil penelitian ini mendukung penelitian sebelumnya yang dilakukan oleh Anis Syamsu Rizal tahun 2019 dengan hasil penelitian menunjukkan bahwa terdapat pengaruh motivasi kerja dan kedisiplinan terhadap kinerja guru dengan besar pengaruh motivasi kerja dan kedisiplinan terhadap kinerja guru sebesar $50 \%$, sisanya sebesar $50 \%$ dipengaruhi oleh faktor lain. ${ }^{2}$

Serta didukung oleh Penelitian ini dilakukan oleh Kaliri Tahun 2008. Hasil penelitiannya menunjukkan terdapat pengaruh secara simultan disiplin dan motivasi kerja terhadap kinerja guru di SMA Negeri di Kabupaten Pemalang. Dengan nilai $F_{\text {hitung }}=12,756$ dengan signifikansi $\mathrm{F}$ sebesar o,ooo. Dengan menggunakan tingkat signifikasi $5 \%$ maka nilai $\mathrm{F}_{\text {tabel }}$ dengan $\mathrm{df}=$ 2 dan $\mathrm{df}_{2}=\mathrm{n}-\mathrm{k}-\mathbf{1}=96-\mathbf{- 1}=93$ diperoleh $\mathrm{F}_{\text {tabel }}$ sebesar 3,12. Maka F hitung $(166,177)$. F tabel $(3,44)$, atau signifikansi F sebesar o,oooo menunjukkan lebih kecil dari o,05. Dengan demikian $\mathrm{H}_{\mathrm{o}}$ ditolak dan $\mathrm{H}_{\mathrm{a}}$ diterima, sehingga hipotesis yang menyatakan ada pengaruh yang positif dan signifikan antara variabel (disiplin /X1 dan motivasi kerja /X2) secara bersama-sama terhadap variabel terikat (kinerja guru / Y) dapat diterima. ${ }^{2}$ Hal ini mengidentifikasi bahwa motivasi kerja dan disiplin kerja berpengaruh terhadap kinerja seorang guru. Menurut Gibson, ada tiga faktor yang mempengaruhi kinerja. Tiga faktor tersebut yaitu: 1) Faktor individu (kemampuan, keterampilan, latar belakang keluarga, pengalaman kerja, tingkat sosial dan demografi seseorang). 2) Faktor psikologis (persepsi, sikap,

2 Rizal, Pengaruh Motivasi Kẻrja, 17.

2 Kaliri, Pengaruh Disiplin dant Motivasi Kerja, 125. 
kepribadian, belajar dan motivasi). 3). Faktor organisasi (struktur organisasi, desain pekerjaan, kepemimpinan, sistem penghargaan atau reward system. ${ }^{2}$

\section{Simpulan}

Penelitian ini menunjukkan bahwa 1) Motivasi kerja guru di Madrasah Tsanawiyah Negeri 2 Bondowoso rata-rata berkategori tinggi sebanyak 67\%. 2) Disiplin kerja guru di Madrasah Tsanawiyah Negeri 2 Bondowoso rata-rata berkategori sangat tinggi sebesar 80\%. 3) Kinerja guru di Madrasah Tsanawiyah Negeri 2 Bondowoso ratarata berkategori tinggi sebesar $67 \%$. 4) Terdapat pengaruh signifikan motivasi kerja dan disiplin kerja secara bersama-sama terhadap kinerja guru di Madrasah Tsanawiyah Negeri 2 Bondowoso dengan hasil uji F diperoleh nilai $F_{\text {hitung }}$ sebesar = 3,6o6 lebih besar dari $F_{\text {tabel }}$ $=3,340.5$ ) Terdapat pengaruh signifikan motivasi kerja dan disiplin kerja secara individu terhadap kinerja guru di Madrasah Tsanawiyah Negeri 2 Bondowoso.

\section{Referensi}

Arisandy, Desy. Hubungan antara Persepsi Karyawan terhadap Disiplin Karyawan Bagian Produksi Kramik "Ken Lila Production". Jurnal psyche 1 No 2. (2004).

Eliyanto, "Pengaruh Motivasi Kerja dan Lingkungan Kerja terhadap Kinerja Guru SMA Muhammadiyah di Kabupaten Kebumen." Jurnal Pendidikan Madrasah 3, no.1. (2018).

Farihah, Umi. "Analisis Pengaruh Kebijakan Peningkatan Profesionalisme Guru terhadap Prestasi Kerja Guru.” Jurnal Internasional Manajemen Pendidikan (2010).

Husnan dan Heidjrachman. Manajemen Personalia, Yogyakarta: BPFE, 2002.

\footnotetext{
2 Farihah, Analisis Pengaruh, 121.
} 
Indriani \& Sutanto. "Hubungan Lingkungan Kerja, Disiplin Kerja, dan Kinerja Karyawan," Jurnal Manajemen dan Kewirausahaan 17, no. 2, (2015).

Kaliri, "Pengaruh Disiplin dan Motivasi Kerja terhadap Kinerja Guru pada SMA Negeri di Kabupaten Pemalang." Tesis. Universitas Negeri Semarang (2008)

Madjid, Abdul. Pengembangan Kinerja Guru, Yogyakarta: Samudra Biru, 2016.

Mangkunegara, Anwar Prabu, Manajemen Sumberdaya Manusia Perusahaan, Bandung: PT Remaja Rosdakarya, 2014.

Ningsih, Mustika Sulistio. "Pengaruh Motivasi Kerja terhadap Kinerja Guru di MA Al-Hikmah Wayhalim Kedaton Bandar Lampung." Skripsi, UIN Raden Intan Lampung (2017).

Rasto dan Utari. "Pengaruh Disiplin Kerja terhadap Kinerja Guru". Jurnal pendidikan manajemen perkantoran 4, no. 2 (Juli 2019).

Rizal, Anis Syamsu. "Pengaruh Motivasi Kerja dan Disiplin Kerja terhadap Kinerja Guru SMP”. Jurnal Ulul Albab 23, No. 1 (2019).

Rodliyah, Siti. Manajemen Pendidikan Sebuah Konsep dan Aplikasi, Jember: IAIN Jember Press. 2015.

Sinambela, Lijat Poltak. Manajemen Sumber Daya Manusia. Jakarta: PT Bumi Aksara.

Sutrisno, Edy. Manajemen Sumber Daya Manusia. Jakarta: Prenadamedia Grub, 2019.

Tsauri, Sofyan. Mananjemen Sumber Daya Manusia. Jember: STAIN Jember Press. 2013.

Uno, Hamzah B. Teori Motivasi Kerja dan Pengukurannya. Jakarta: Bumi Aksara, 2019. 
JIEMAN: Journal of Islamic Educational Management

Usmani, Husaini. Manajemen Teori, Praktik, dan Riset Pendidikan, Jakarta: PT Bumi Aksara, 2016.

Undang-Undang Nomor 14 Tahun 2005 tentang Guru dan Dosen. 